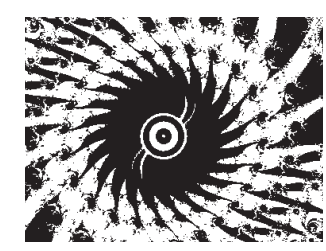

\title{
ZAPOSLENOST OSOBA S INVALIDITETOM U HRVATSKOJ I ZEMLJAMA EUROPSKE UNIJE
}

Zdravka LEUTAR, Marko BULJEVAC Pravni fakultet, Zagreb

UDK: 331.526-056.26(497.5:4-6EU)

Izvorni znanstveni rad

Primlieno: 29. 9. 2010.

U uvodnom dijelu prikazana su osnovna obiliežja zapošljavanja osoba s invaliditetom u 27 zemalja Europske unije (EU) i u Hrvatskoj. Potom slijedi prikaz rezultata istraživanja "Socijalni položai osoba s invaliditetom u Hrvatskoj" u kontekstu zaposlenosti osoba s invaliditetom u Hrvatskoj. Cilj ovog rada jest ispitati neka obiliežja zaposlenih osoba s invaliditetom u Hrvatskoj i usporediti ih sa zemljama EU-a, utvrditi materijalne prilike osoba s invaliditetom u Hrvatskoj i uključenost u zajednicu zaposlenih osoba s invaliditetom. Istraživanje je provedeno anketnim ispitivanjem na uzorku od 689 ispitanika u Hrvatskoj. Rezultati istraživanja pokazuju da je zaposlenost osoba s invaliditetom u Hrvatskoj oko $10 \%$. Postoje statistički značajne razlike u radnom statusu s obzirom na stupanj obrazovanja, redovito školovanje i vrijeme nastanka invaliditeta. Postoji i povezanost samoprocjene i objektivne procjene materijalnih prilika, zaposlenosti te uključenosti u zajednicu. Hrvatska ne odstupa od prosjeka zaposlenosti osoba s invaliditetom zemalja EU-a, gdje prevladava kvotni način zapošljavanja na otvorenom tržištu rada. Potrebno je ulagati u obrazovanje osoba s invaliditetom i osposobljavati ih za zanimanja poželina na otvorenom tržištu rada te poticati njihovu uključenost u zajednicu.

Ključne riječi: zaposlenost, Hrvatska, zemlje EU-a, obrazovanje, uključenost u zajednicu

Zdravka Leutar, Pravni fakultet Sveučilišta u Zagrebu, Studijski centar socijalnog rada, Nazorova 51, 10000 Zagreb, Hrvatska.

E-mail: zdravka.leutar@pravo.hr 
Zakonodavstva raznih država različito definiraju pojmove invaliditet i osoba s invaliditetom. Upravo zbog neujednačenosti definiranja i shvaćanja navedenih pojmova, Konvencija UN-a o pravima osoba s invaliditetom navodi kako je invaliditet koncept koji se još uvijek razvija te nastaje kao rezultat međudjelovanja osoba s oštećenjima i zapreka koje proizlaze iz stajališta njihove okoline i zapreka koje postoje u okolišu, a koje onemogućuju njihovo puno i djelotvorno sudjelovanje u društvu na ravnopravnoj osnovi s drugim građanima (Zakon o potvrđivanju Konvencije o pravima osoba s invaliditetom i fakultativnog protokola uz konvenciju o pravima osoba s invaliditetom, NN 6/2007., 3/2008., 5/2008.). Zapošljavanje osoba s invaliditetom jedno je od prioritetnih područja politika država članica Europske unije (EU), jer se njime ostvaruje punopravno uključivanje u zajednicu samih osoba s invaliditetom. Zaposlenjem takva osoba stječe materijalnu sigurnost, veću samostalnost u odlučivanju u svojem životu, članovi zajednice drugačije ju percipiraju. Pravo na rad nerijetko je osporavano pravo osoba s invaliditetom. Stoga se politikama zapošljavanja za osobe s invaliditetom ostvaruje njihovo punopravno sudjelovanje $u$ društvu. Osobe s invaliditetom zapošljavaju se pod općim i posebnim uvjetima. Europske države od početka 20. stoljeća provode sljedeće politike zapošljavanja osoba s invaliditetom, utemeljene na medicinskom modelu invaliditeta: zaštitno zapošljavanje kroz slabije plaćene poslove, pomoćna zanimanja utemeljena na ispomoći, kvotno zapošljavanje putem pozitivne diskriminacije te poticanje i prihvaćanje zapošljavanja osoba s invaliditetom zbog rasta utjecaja međunarodnih pokreta osoba s invaliditetom (Goss i sur., 2000.).

Prije zapošljavanja osoba s invaliditetom postoje programi profesionalne rehabilitacije koji se odnose na povećanje zapošljivosti osoba s invaliditetom. Programima profesionalne rehabilitacije, ali i programima doškolovanja, osobe s invaliditetom stječu određena znanja i vještine kako bi bile konkurentnije prilikom traženja posla. Programi profesionalne rehabilitacije vide se u svim zemljama članicama EU-a i u Hrvatskoj. Osim navedenih programa, u većini zemalja prisutni su i programi potpomognutoga zapošljavanja.

Prema European Community Household Panel (ECHP), vjerojatnost pronalaska ili pokretanja posla kod osobe bez invaliditeta iznosi $66 \%$, osobe s lakšim invaliditetom $47 \%$, dok za osobe s težim invaliditetom 25\% (European Disability Forum, 2003.). Istraživanje u 25 zemalja EU-a o tržištu rada osoba $s$ invaliditetom (Shima i sur., 2008.) upućuje na rast zaposlenosti osoba s invaliditetom u svim zemljama EU-a, osim u Češkoj i Poljskoj. Zaštitno zapošljavanje najčešće je u Belgiji i Italiji, dok se osobe s invaliditetom najčešće zapošljavaju na otvorenom tržištu rada u Slovačkoj, Ceškoj, Austriji i Njemačkoj. 


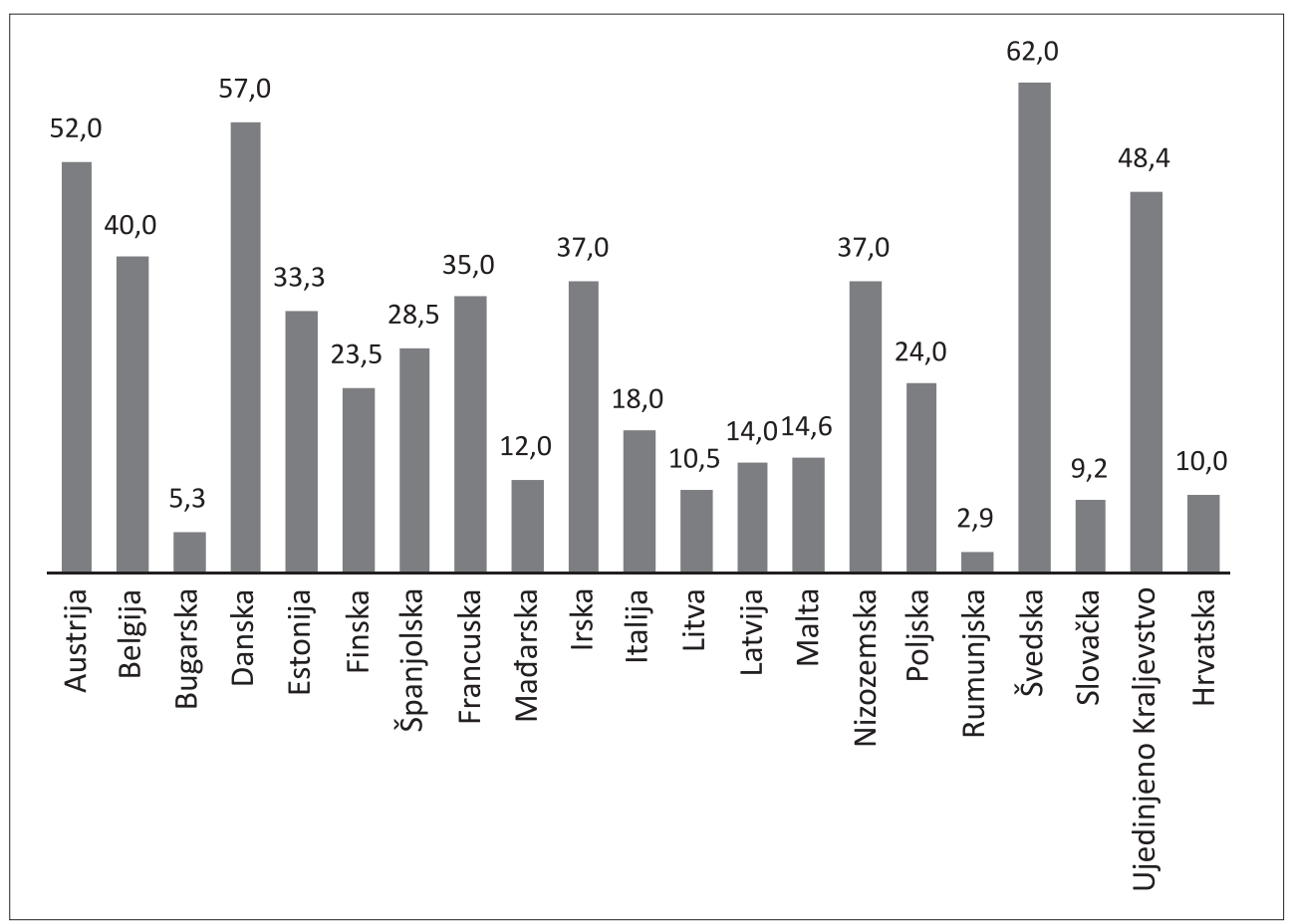

Izvor: Bengtsson, 2009.; Burton i O’Mahony, 2009.; Calite, 2009.; Danermark, 2009.; Devlieger, 2008.; Ghergut i Gavrilovici, 2008.; Hanzelova i sur., 2009.; Hrvatski zavod za zapošljavanje, 2010.; Koenig, 2009.; Konczei i Horvath, 2008.; Kummissjoni Nazzjonali Persuni B'dizabilita, 2009.; Micangeli i sur., 2009.; Panayotova, 2009.; Roulstone i sur., 2009.; Ruškus, 2009.; Sakkeus i sur., 2009.; Schoonheim i Smits, 2009.; Strati i Evangelinou, 2009.; Velche i sur., 2009.; Verdugo i sur., 2009.; Wapiennik, 2009.

it SLIKA 1

Stopa zaposlenih osoba s invaliditetom od ukupnoga broja osoba s invaliditetom u zemliama Europske unije i u Hrvatskoi (\%)
Podaci prikazani u Tablici 1 o stopama zaposlenosti osoba s invaliditetom pokazuju kako je najveći broj osoba s invaliditetom zaposlen u Švedskoj, Danskoj, Austriji, Ujedinjenom Kraljevstvu, Nizozemskoj i Irskoj, dok je najmanji broj osoba s invaliditetom zaposlen u Rumunjskoj, Bugarskoj, Slovačkoj i Hrvatskoj. Nacionalna izvješća Cipra, Češke, Grčke, Luksemburga, Njemačke, Portugala i Slovenije ne navode broj zaposlenih osoba s invaliditetom. Pojedina nacionalna izvješća navode postotak nezaposlenih osoba s invaliditetom od 17,4\% osoba s invaliditetom u Češkoj (Šiška, 2009.), 14,5\% u Njemačkoj (Waldschmidt i sur., 2009.), 8,9\% u Grčkoj (Strati i Evangelinou, 2009.), 19\% u Francuskoj (Velche i sur., 2009.), 14,83\% u Sloveniji (Flaker i sur., 2009.), 13,7\% u Poljskoj (Wapiennik, 2009.), 9,5\% u Portugalu (Pimenta i Marques, 2009.), 8,5\% u Slovačkoj (Hanzelova i sur., 2009.) i 6,3\% u Švedskoj (Danermark, 2009.). Osim stope zaposlenih i nezaposlenih osoba s invaliditetom od ukupnoga broja osoba s invaliditetom u pojedinoj državi, poznati su i podaci o stopama osoba s invalidi- 
DRUŠ. ISTRAŽ. ZAGREB GOD. 21 (2012)

BR. 1 (115)

STR. 79-100

LEUTAR, Z., BULJEVAC, M. ZAPOSLENOST OSOBA...

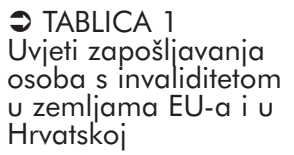

tetom koje su radno neaktivne. Broj radno neaktivnih osoba s invaliditetom od ukupnoga broja osoba s invaliditetom iznosi 21\% u Austriji (Koenig, 2009.), 76\% u Poljskoj (Wapiennik, 2009.), 72,5\% u Slovačkoj (Hanzelova i sur., 2009.), 70\% u Sloveniji (Flaker i sur., 2009.) te $84 \%$ osoba s invaliditetom u Grčkoj (Strati i Evangelinou, 2009.).

\begin{tabular}{|c|c|c|c|c|}
\hline $\begin{array}{r}\mathrm{O} \\
\mathrm{p} \\
\mathrm{zap}\end{array}$ & $\begin{array}{l}\text { Olakšice i poticaji } \\
\text { poslodavcima pri } \\
\text { apošljavanju osoba } \\
\text { s invaliditetom }\end{array}$ & $\begin{array}{l}\text { Kvotni } \\
\text { sustav }\end{array}$ & $\begin{array}{c}\text { Zaštitno } \\
\text { zapošljavanje }\end{array}$ & $\begin{array}{l}\text { Samoza- } \\
\text { pošljavanje }\end{array}$ \\
\hline Austrija & + & + & + & + \\
\hline Belgija & + & + & + & \\
\hline Bugarska & + & + & + & + \\
\hline Cipar & + & + & + & + \\
\hline Češka & + & + & + & \\
\hline Njemačka & + & + & + & \\
\hline Danska & + & & + & \\
\hline Estonija & + & & + & \\
\hline Grčka & + & + & + & + \\
\hline Španjolska & + & + & + & \\
\hline Finska & + & & + & \\
\hline Francuska & + & + & + & + \\
\hline Mađarska & + & + & + & \\
\hline Irska & + & + & + & \\
\hline Italija & + & + & + & \\
\hline Litva & + & + & + & \\
\hline Luksemburg & + & + & + & \\
\hline Latvija & + & & + & \\
\hline Malta & + & + & + & + \\
\hline Nizozemska & + & & + & \\
\hline Poljska & + & + & + & + \\
\hline Portugal & + & + & + & + \\
\hline Rumunjska & + & & + & \\
\hline Švedska & + & & + & + \\
\hline Slovačka & + & + & + & + \\
\hline Slovenija & + & + & + & + \\
\hline \multicolumn{5}{|l|}{ Ujedinjeno } \\
\hline Kraljevstvo & + & & + & + \\
\hline Hrvatska & + & + & + & + \\
\hline
\end{tabular}

Izvor: Bengtsson, 2009.; Burton i O’Mahony, 2009.; Calite, 2009.; Ceccotto, 2008.; Danermark, 2009.; Devlieger, 2008.; Flaker i sur., 2009.; Ghergut i Gavrilovici, 2008.; Hanzelova i sur., 2009.; Hrvatski zavod za zapošljavanje, 2010.; Koenig, 2009.; Konczei i Horvath, 2008.; Kummissjoni Nazzjonali Persuni B'dizabilita, 2009.; Micangeli i sur., 2009.; Panayotova, 2009.; Pimenta i Marques, 2009.; Roulstone i sur., 2009.; Ruškus, 2009.; Sakkeus i sur., 2009.; Schoonheim i Smits, 2009.; Strati i Evangelinou, 2009.; Symeonidou, 2008.; Šiška, 2009.; Velche i sur., 2009.; Verdugo i sur., 2009.; Waldschmidt i sur., 2009.; Wapiennik, 2009.; Zakon o profesionalnoj rehabilitaciji i zapošljavanju osoba s invaliditetom (NN 143/2002., 33/2005.) 
DRUŠ. ISTRAŽ. ZAGREB GOD. 21 (2012), BR. 1 (115)

STR. $79-100$

LEUTAR, Z., BULJEVAC, M. ZAPOSLENOST OSOBA...
Prema nacionalnim izvješćima, u svim zemljama EU-a i u Hrvatskoj postoje olakšice i poticaji poslodavcima pri zapošljavanju osoba s invaliditetom, neovisno o tome je li riječ o zapošljavanju na otvorenom tržištu rada ili o zapošljavanju u posebnim uvjetima.

Olakšice i poticaju najčešće su sredstva za prilagodbu radnoga mjesta i uvjeta rada, usluge asistenata u radu, novčani poticaji, određene porezne olakšice itd. Tako je u Italiji asistente u radu putem "Job desks" koristilo 6000 osoba (Micangeli i sur., 2009.), dok u Njemačkoj djeluju programi "Job 4000" i "Job Budget", koji pridonose uključivanju osoba s težim invaliditetom $\mathrm{u}$ otvoreno tržište rada i smanjenju zaštitnoga zapošljavanja (Waldschmidt i sur., 2009.).

Zaštitno zapošljavanje zastupljeno je i u svim državama članicama EU-a, ali i u Hrvatskoj. U Njemačkoj postoji 687 zaštitnih radionica da bi se osigurao transfer na otvoreno tržište (International Disability Rights Monitor, 2007.), dok se u Mađarskoj također potiče prijelaz iz zaštitnog rada na otvoreno tržište rada, iako je 2008. godine čak 18346 osoba bilo zaposleno u zaštitnim ustanovama (Konczei i Horvath, 2008.). U Sloveniji su 23 državne i 11 koncesioniranih zaštitnih radionica (Flaker i sur., 2009.), dok Panayotova (2009.) navodi da u Bugarskoj postoji 91 specijalizirana organizacija koja zapošljava 14572 osobe s invaliditetom. Za razliku od većine zemalja EU-a, na Malti se zaštitno zapošljavanje smatra alternativnim oblikom koji treba osigurati prijelaz na otvoreno tržište (Kummissjoni Nazzjonali Persuni B'dizabilita, 2009.).

Kvotni sustav odnosi se na zapošljavanje osoba na otvorenom tržištu rada, na temelju kojeg se zahtijeva od poslodavca da od ukupnoga broja zaposlenih ima određeni postotak zaposlenika s invaliditetom. Najčešće se odnosi na državni sektor, iako se sve češće zakonom obvezuje i privatni sektor poslodavaca. Države koje nemaju kvotne sustave kao oblik i mjeru zapošljavanja osoba s invaliditetom jesu Danska, Estonija, Finska, Nizozemska, Latvija, Rumunjska, Švedska i Ujedinjeno Kraljevstvo. Stoga u Danskoj poslodavci mogu osnivati zasebne radne odjele za zaposlenike s invaliditetom (Bengtsson, 2009.), u Finskoj je prisutna negativna percepcija kvotnoga sustava od samih osoba s invaliditetom (International Disability Rights Monitor, 2007.), dok je u Švedskoj izrazito razvijeno samozapošljavanje (Danermark, 2009.). Samozapošljavanje kao oblik zapošljavanja istaknuto je $\mathrm{u}$ zakonodavstvima i programima 13 država EU-a, prikazanih u Tablici 1. Stoga je Austrija država s visokom stopom zaposlenih osoba s invaliditetom, na što upućuje i podatak kako je na temelju Disability Employment Acta 2002. godine osigurana integracija za 80532 osobe, od kojih je 68\% bilo zaposleno ili samozaposleno (Soritsch, 2004.). Na temelju mikrokredita za samozapošljavanje, u Portugalu je do prosinca 2006. godine 
DRUŠ. ISTRAŽ. ZAGREB GOD. 21 (2012),

BR. 1 (115),

STR. 79-100

LEUTAR, Z., BULJEVAC, M. ZAPOSLENOST OSOBA... otvoreno 745 radnih mjesta (Pimenta i Marques, 2009.). Rezultati ECHP-a upućuju na češće samozapošljavanje osoba s invaliditetom negoli osoba bez invaliditeta, uz najviše stope samozaposlenih osoba s invaliditetom u Grčkoj (50\%), dok manje od 10\% samozaposlenih bilježe Francuska, Danska i Nizozemska (Pagan, 2009.). Prema navedenom autoru, u Italiji su češće zaposleni muškarci s invaliditetom (30\%), a žene s invaliditetom u Španjolskoj $(25,44 \%)$ i Portugalu $(33,4 \%)$

U Hrvatskoj je zapošljavanje osoba s invaliditetom regulirano Zakonom o profesionalnoj rehabilitaciji i zapošljavanju osoba s invaliditetom (NN, 143/2002., 33/2005.), na temelju kojeg se razlikuje zapošljavanje pod općim uvjetima i zapošljavanje pod posebnim uvjetima. Zapošljavanje pod općim uvjetima regulirano je tzv. kvotnim sustavom zapošljavanja od 2005. do 2017. godine. Pod općim uvjetima zapošljavanja smatra se zapošljavanje osoba s invaliditetom po općim propisima, koji uređuju područje rada i zapošljavanja na otvorenom tržištu rada, dok se pod posebnim uvjetima zapošljavanja misli na zapošljavanje u ustanovi ili trgovačkom društvu osnovanom radi zapošljavanja osoba $\mathrm{s}$ invaliditetom $\mathrm{u}$ zaštitnim radionicama, kao i samozapošljavanje osoba s invaliditetom. Osobe s invaliditetom $\mathrm{u}$ radnim centrima nalaze se $\mathrm{u}$ prostoru između radne okupacije koju regulira Zakon o socijalnoj skrbi i radnog odnosa po posebnim uvjetima (zaštitne radionice), odnosno općim uvjetima (otvoreno tržište).

\section{CILJ ISTRAŽIVANJA}

Cilj istraživanja jest ispitati:

- Zaposlenost osoba s invaliditetom u Hrvatskoj i usporediti je sa zemljama EU-a.

- Utvrditi materijalne prilike nezaposlenih osoba s invaliditetom u Hrvatskoj te materijalne prilike zaposlenih osoba s invaliditetom u Hrvatskoj.

- Utvrditi uključenost u zajednicu zaposlenih osoba s invaliditetom.

\section{METODA}

\section{Sudionici istraživanja i postupak}

Podaci su prikupljeni u istraživanju Ministarstva obitelji, branitelja i međugeneracijske solidarnosti "Socijalni položaj osoba s invaliditetom u Hrvatskoj" 2009. godine na uzorku od 689 ispitanika, koji čini podjednak broj muških i ženskih ispitanika, prosječne dobi 34,6 godina. Podjednako su zastupljeni ispitanici u urbanim i ruralnim područjima.

Studenti Studijskoga centra socijalnog rada Pravnoga fakulteta Sveučilišta u Zagrebu odabrani su za anketare i educirani za provođenje istraživanja. Metodom slučajnog odabira odabrano je 28 centara za socijalnu skrb (CZSS), na čijem je 
DRUŠ. ISTRAŽ. ZAGREB GOD. 21 (2012), BR. 1 (115),

STR. $79-100$

LEUTAR, Z., BULJEVAC, M.: ZAPOSLENOST OSOBA... području istraživanje provedeno. Obuhvaćeno je cijelo geografsko područje Hrvatske. U svakom CZSS-u zamoljeno je da se s popisa korisnika odabere svaki 10. korisnik kako bi se ostvario slučajni uzorak od 25 ispitanika po pojedinom CZSS-u. Imena ispitanika dobivena su od socijalnih radnika nadležnih za područje osoba s invaliditetom. Budući da se u pojedinim CZSS-ima nisu iz određenih razloga pridržavali zamoljenog, zatražena je pomoć lokalnih udruga osoba s invaliditetom. Stoga se odabir ispitanika temeljio na odabiru socijalnog radnika, koji je izdvojio po 25 korisnika CZSS-a, zastupljenosti osoba s invaliditetom svih vrsta oštećenja te članstva u udruzi osoba s invaliditetom ako se nije moglo provesti preko CZSS-a. Radi se o slučajnom odabiru CZSS-a, ali o prigodnom uzorku ispitanika, jer je sudjelovanje $u$ istraživanju određeno činjenicom da su ispitanici bili ili korisnici CZSS-a ili članovi udruga osoba s invaliditetom. Budući da navedeno predstavlja ograničenje istraživanja, prikupljeni su podaci ponderirani.

Ponderiranje po dizajnu uzorka primjenjuje se kad ispitanici nemaju jednaku mogućnost izbora u uzorak (u ovom slučaju zato što CZSS-i imaju različit broj korisnika koji predstavljaju populaciju). Time su korisnici pojedinih CZSS-ova mogli biti previše ili premalo zastupljeni u uzorku. Ponderiranjem je ostvarena preciznija procjena. Efektivna veličina uzorka jest 391 ispitanik.

Analiza dobivenih rezultata temelji se na ponderiranom uzorku od 191 žene i 199 muškaraca. Istraživanje je provedeno s punoljetnim sudionicima. Oko 35 godina imalo je $32 \%$ ispitanika, $48 \%$ ispitanika do 65 godina, a $20 \%$ ispitanika bilo je starije od 65 godina. Nezavršenu osnovnu školu ima 10,7\% ispitanika, završenu osnovnu školu 21,3\%, trogodišnju strukovnu školu $33,6 \%$, dok četverogodišnju srednju školu ima $23,6 \%$ ispitanika. Višu i visoku školu završilo je 7,2\% ispitanika. Kod 51,6\% ispitanika invaliditet je uslijedio u kasnijoj dobi kao posljedica bolesti ili starosti, dok je invaliditet kod 34,8\% prisutan od rođenja. Invaliditet je nastupio do 18. godine života kod 13,5\% ispitanika.

U istraživanju su sudjelovale osobe među kojima je najveći postotak (72\%) s motoričkim oštećenjima i u kombinaciji $\mathrm{s}$ drugim tjelesnim oštećenjima. Oštećenje vida prisutno je kod 22,5\% ispitanika, oštećenje sluha kod 14,5\%, dok osobe s intelektualnim teškoćama čine 19,6\% ispitanika. Teški ili teži stupanj invaliditeta procjenjuje $67,8 \%$ ispitanika, umjereni stupanj oštećenja njih $20,3 \%$, dok $11,9 \%$ procjenjuje svoj stupanj oštećenja lakšim. Navedene procjene težine invaliditeta rezultat su samoprocjene ispitanika. Oženjeno/udano je $43 \%$ ispitanika, neudano/neoženjeno $43,5 \%$, razvedeno $2 \%$, a 8,3\% ispitanika udovac/udovica. S članovima vlastite obitelji živi $39,3 \%$ ispitanika, u instituciji $5 \%$. Ukupno $11,2 \%$ ispitanika 
DRUŠ. ISTRAŽ. ZAGREB GOD. 21 (2012),

BR. 1 (115),

STR. $79-100$

LEUTAR, Z., BULJEVAC, M. ZAPOSLENOST OSOBA...

Instrumenti žive sami. S roditeljima živi 30,5\% ispitanika, dok s partnerom $15 \%$. S obzirom na mjesto prebivanja, u gradu iznad 100000 stanovnika živi 8,3\% ispitanika, 16,6\% živi u mjestu do 1000 stanovnika. Najveći postotak ispitanika $(35,1 \%)$ živi u gradu između 10000 i 100000 stanovnika. Oko 37\% stanovnici su manjih gradova i općinskih središta.

Ispitivanje je provedeno polustrukturiranim anketnim upitnikom konstruiranim za navedeno istraživanje. Upitnik je sadržavao varijable vezane uz različita životna područja. Dio upitnika preuzet je iz ranijeg istraživanja "Obitelji osoba s invaliditetom" (Leutar, 2002., prema Leutar i sur., 2008.). Za potrebe ovog rada izdvojene su varijable koje određuju zapošljavanje osoba s invaliditetom.

\section{Socioekonomski status}

Socioekonomski status čine varijable koje se odnose na izvore prihoda ispitanika (osobna invalidnina, obiteljska mirovina, invalidska mirovina, dječji dodatak, doplatak za pomoć i njegu u kući, naknada do zaposlenja, vlastita zarada, nešto drugo) i samoprocjenu materijalnih prilika (1 - jako dobre; 2 - dobre; 3 - osrednje; 4 - loše; 5 - jako loše).

U ovu skupinu varijabli ulaze i prosječna materijalna primanja u zadnja tri mjeseca. Vlastita percepcija materijalnih prilika procjenjivana je na skali od pet stupnjeva: 1 - odlične, 2 - vrlo dobre, 3 - dobre, 2 - loše, 1 - jako loše. Druga varijabla odnosila se na subjektivnu procjenu siromaštva.

\section{Zapošljavanje osoba s invaliditetom}

Varijable koje se odnose na radni status i zapošljavanje osoba s invaliditetom jesu: radni status, zaposlenost, sigurnost na poslu i vrsta zaposlenosti.

\section{Skala uključenosti u zajednicu}

Da bi se ispitala uključenost u zajednicu, sastavljeno je 6 tvrdnji. Sudionici su na ljestvici od pet stupnjeva označavali u kolikoj su mjeri uključeni u pojedine aktivnosti u zajednici: 1 - nikad, 2 - rijetko, 3 - ponekad, 4 - često, 5 - uvijek. Faktorskom analizom utvrđena je valjanost.

Provjera metrijskih karakteristika podskala provedena je faktorskom analizom, metodom glavnih komponenata uz Kaiser-Guttmanov kriterij za zaustavljanje ekstrakcije u bazičnoj soluciji te varimax-transformacijom za određivanje jednostavne strukture. U Tablici 2 sadržana su faktorska opterećenja čestica. To su korelacije svake pojedinačne varijable sadržane u podskali s faktorom. Visina korelacije pokazuje važ- 
DRUŠ. ISTRAŽ. ZAGREB GOD. 21 (2012),

BR. 1 (115)

STR. $79-100$

LEUTAR, Z., BULJEVAC, M.: ZAPOSLENOST OSOBA...

(1) TABLICA 2

Faktorska struktura skale uključenosti u zajednicu
Bartlettov test sfericiteta pokazuje kako je vrijednost $\chi^{2}$ statistički značajna $\left(\chi^{2}=818,763 ; \mathrm{df}=15 ; \mathrm{p}<0,01\right)$ te potvrđuje kako matrica korelacija manifestnih varijabli značajno odstupa od jedinične matrice koja odražava nulte korelacije među varijablama, odnosno ima dovoljno značajnih korelacija za provedbu faktorske analize.

U faktorsku analizu ušlo je svih šest varijabli, koje zajedno čine 1 faktor "uključenosti u zajednicu". On opisuje 58,48\% varijabiliteta manifesnih varijabli, što je pokazatelj dobre konstruktne valjanosti skale uključenosti u zajednicu.

\begin{tabular}{lc}
\hline & $\begin{array}{r}\text { Komponente } \\
1 \text { faktor }\end{array}$ \\
\hline Sudjelujem u političkom životu zajednice & 0,695 \\
Iskorištavam svoje osobne potencijale za dobrobit zajednice & 0,832 \\
Primam informacije o događanjima u zajednici & 0,775 \\
Sam se informiram o događanjima u zajednici & 0,825 \\
Koristim se resursima lokalne zajednice (npr. prostorijama, biciklističkim stazama, \\
parkovima, športskim terenima i sl.) & 0,712 \\
Susrećem utjecajne članove zajednice & 0,740 \\
Karakteristični korijen & 3,509
\end{tabular}

\section{REZULTATI I RASPRAVA}

\section{Zaposlenost osoba s invaliditetom}

U Hrvatskoj se zabilježeni postotak osoba s invaliditetom kreće od 9,7\% (Državni zavod za statistiku, 2001.) do 11,9\% (Benjak, 2011.). Iako nema službenih podataka, procjenjuje se da je oko 40000 osoba ili 9,3\% osoba s invaliditetom u radnom odnosu (Paun Jarallah, 2008., Hrvatski zavod za zapošljavanje, 2011.). Izvješće o osobama s invaliditetom u Republici Hrvatskoj navodi 14073 zaposlenih osoba s invaliditetom (Benjak, 2011.), međutim treba uzeti u obzir kako Registar o osobama s invaliditetom uzima podatke dobivene iz točno određenih sustava u kojima osobe s invaliditetom mogu koristiti svoja prava. Slijedi prikaz rezultata ovog istraživanja o radnom statusu ispitanika, s posebnim naglaskom na analizi dviju skupina ispitanika, a to su zaposlene i nezaposlene osobe s invaliditetom.

Rezultati upućuju na najveći postotak nezaposlenih osoba s invaliditetom (42,2\%). Zaposleno je 11,3\% ispitanika, dok su 38,5\% korisnici nekih oblika mirovine, uz 1,6\% studenata. Nešto drugo odgovorilo je 6,4\% ispitanika, koji smatraju da njihov stupanj invaliditeta ne dopušta ikakav rad i nisu korisni- 
DRUŠ. ISTRAŽ. ZAGREB GOD. 21 (2012), BR. $1(115)$

STR. 79-100

LEUTAR, Z., BULJEVAC, M. ZAPOSLENOST OSOBA...

$\rightarrow$ TABLICA 3

Radni status ispitanika ci mirovine. U istraživanju Leutar (2006.) najveći postotak čine osobe s invaliditetom korisnici mirovine (46,6\%), zatim nezaposlene osobe s invaliditetom $(31,3 \%)$, dok je zaposlenih $12,9 \%$, što upućuje na vrlo slične rezultate dobivene na različitoj populaciji osoba s invaliditetom $u$ dva različita istraživanja. Hrvatski zavod za zapošljavanje (2011.) također navodi podatak od oko $10 \%$ zaposlenih osoba s invaliditetom. Iako ranije navedeni podaci Registra o osobama s invaliditetom pokazuju manji postotak zaposlenih s invaliditetom, mora se uzeti $\mathrm{u}$ obzir da postoji dio populacije osoba s invaliditetom koje nisu korisnici prava sustava što dostavljaju podatke Registru o osobama s invaliditetom.

\begin{tabular}{lrr}
\hline Radni status & Broj & $\%$ \\
\hline Zaposleni & 44 & 11,3 \\
Nezaposleni & 164 & 42,2 \\
Korisnici mirovina & 149 & 38,5 \\
Studenti & 6 & 1,6 \\
Nešto drugo & 25 & 6,4 \\
Ukupno & 388 & 100,0
\end{tabular}

Službene statistike za 2009. godinu pokazuju da je gospodarska kriza utjecala na položaj osoba s invaliditetom na tržištu rada. Potkraj 2009. godine evidencije HZZ-a bilježe 6215 nezaposlenih osoba s invaliditetom, uz podatak da se broj zaposlenih osoba s invaliditetom $u$ usporedbi sa 2007. godinom na području Hrvatske smanjio za više od 400 osoba te je 2009. godini novozaposleno 1028 osoba s invaliditetom (Hrvatski zavod za zapošljavanje, 2010.). Službeni podaci pokazuju kako je potkraj 2010. godine u evidenciji bilo registrirano 6255 nezaposlenih osoba s invaliditetom, dok se tijekom iste godine na temelju evidencije Zavoda zaposlilo 1080 osoba s invaliditetom (Hrvatski zavod za zapošljavanje, 2011.). Istraživanje Kiš-Glavaš (2009.) pokazuje kako su osobe s invaliditetom u Hrvatskoj nedovoljno aktivne u traženju posla, što se može povezati s rezultatom istraživanja UNDP-a (2008.) da se čak $42,8 \%$ ispitanika priviklo i donekle zadovoljno statusom nezaposlene osobe. Rezultati navedenog istraživanje također pokazuju da je 52,2\% ispitanika nezaposleno dulje od 5 godina te da $47,3 \%$ ispitanika uopće nema radnog iskustva. Istraživanja u zemljama EU-a navode slične probleme. Rezultati istraživanja opće uprave za zapošljavanje i socijalna pitanja Europske komisije i 7 organizacija osoba s invaliditetom pokazuju da $42 \%$ osoba s invaliditetom živi od prava na temelju invaliditeta, dok ih je 20,8\% nezaposleno. Ako su zaposlene, čak $57 \%$ osoba s invaliditetom radi slabije plaćene poslove (European Disability Forum, 2003.). Rezultati istraživanja Euro- 
DRUŠ. ISTRAŽ. ZAGREB GOD. 21 (2012), BR. 1 (115)

STR. $79-100$

LEUTAR, Z., BULJEVAC, M.: ZAPOSLENOST OSOBA... barometer 279 pokazuju da $22 \%$ ispitanika smatra invaliditet razlogom socijalne isključenosti i siromaštva, dok rezultati istraživanja Eurobarometer 296 pokazuju da 41\% ispitanika smatra invaliditet zaprekom prilikom traženja posla (Eurostat, 2010.). U Irskoj Gannon i Nolan (2005.) navode da će osobe kod kojih je invaliditet nastao prije 25 . godine života često ostati nekvalificirane, dok osobe s teškim invaliditetom uopće nemaju mogućnost sudjelovati na tržištu rada. Rezultati istraživanja o invaliditetu u državama Istočne Europe i bivšega Sovjetskog Saveza pokazuju da će osobe s invaliditetom rjeđe pronaći posao u usporedbi s osobama bez invaliditeta, jer velik broj registriranih osoba s invaliditetom ne želi tražiti zaposlenje zbog rizika gubitka stečenih prava, iako zaposlenje štiti osobe $s$ invaliditetom od siromaštva (Mete, 2008.). Podaci za 2002. godinu govore o najvećem broju zaposlenih s invaliditetom u Finskoj $(32,2 \%)$ i najmanjem u Rumunjskoj $(5,8 \%)$ te kako $78 \%$ osoba s težim invaliditetom ne čini radnu snagu u zemljama EU-a (European Communities, 2003.). Možda upravo zbog navedenog države EU-a provode kvotno i zaštitno zapošljavanje. OECD (2002., prema Grammenos, 2003.) navodi da ako se ispuni kvotno zapošljavanje, nema mogućnosti zapošljavanja novih zaposlenika s invaliditetom, što se povezuje sa statističkim pokazateljem da zaštitne radionice EU-a zapošljavaju 500000 osoba.

Rezultati ovog istraživanja pokazuju da zaposleni ispitanici rade najčešće puno radno vrijeme $(83,5 \%)$, dok nepuno radno vrijeme radi $14,3 \%$ ispitanika. Na određeno radno vrijeme zaposleno je $24,7 \%$ ispitanika, uz $73,8 \%$ zaposlenih na neodređeno radno vrijeme. Nadalje, $50 \%$ zaposlenih ispitanika procjenjuje vjerojatnost gubitka posla malom, veliku vjerojatnost procjenjuje $10,9 \%$, uz 38,6\% koji smatraju da vjerojatnost gubitka posla nije ni mala ni velika. Posao koji rade 64,7\% procjenjuje zanimljivim, osrednje zanimljivim $22,8 \%$, a nezanimljivim $12,5 \%$ zaposlenih ispitanika. Rezultati su slični rezultatima istraživanja UNDP-a (2008.), koji pokazuju da je 51,3\% ispitanika zadovoljno poslom, nasuprot $12,9 \%$ nezadovoljnih. Može se zaključiti da zaposleni ispitanici u uzorku odgovaraju populaciji zaposlenih osoba s invaliditetom u Hrvatskoj i prema službenim statistikama i rezultatima ranijih istraživanja. Odrednicama zaposlenja osoba s invaliditetom mogu se smatrati puno radno vrijeme na neodređeno i procjena posla zanimljivim.

Pagan (2007.) navodi da nepuno radno vrijeme u najvećoj mjeri rade žene s invaliditetom u Nizozemskoj $(57,29 \%)$, Irskoj $(45,27 \%)$ i UK $(43,51 \%)$, dok najrjeđe u Finskoj (14,03\%). Muškarci s invaliditetom u nepunom su radnom vremenu najčešće zaposleni u Irskoj i Nizozemskoj (15\%), uz najniži postotak tako zaposlenih u Francuskoj $(4,74 \%)$. To i jesu države u kojima je rad s nepunim radnim vremenom uvelike prisutan i kod opće populacije (Leutar, 2009.). 
$\rightarrow$ TABLICA 4 Statistički značajne razlike s obzirom na sociodemografske pokazatelje
Slijedi analiza zaposlenosti statistički značajnih razlika s obzirom na sociodemografska obilježja.

\begin{tabular}{lrrr}
\hline & $\chi^{2}$ & df & $p$ \\
\hline Vrijeme nastanka invaliditeta & 14,43 & 2 & 0,001 \\
Vrsta škole & 13,55 & 3 & 0,004 \\
Stupanj obrazovanja & 26,32 & 4 & 0,000 \\
\hline
\end{tabular}

Primjenom hi-kvadrat testa došlo se do određenih značajnih razlika prikazanih u Tablici 4 . Utvrđene su razlike u pogledu vremena nastanka invaliditeta. Osobe s kasnije nastalim invaliditetom češće su u radnom odnosu, kao i osobe koje su pohađale školu po redovitom programu is postignutim višim stupnjem obrazovanja. Rezultati upućuju na samo 3 zaposlene osobe sa završenom osnovnom školom. Ranija istraživanja također pokazuju da je obrazovanje u redovitom programu prediktor lakšega zapošljavanja (Leonard i sur., 1999., Hyde, 2000., prema Skočić Mihić i Pinoza Kukurin, 2009.; Leutar i Milić Babić, 2008.; Sokač, 2003., prema Leutar, 2005.; Babić i Leutar, 2010.).

Očekuje se da su materijalne prilike ispitanika povezane sa zaposlenosti. Rezultati o strukturi prihoda pokazuju da ispitanici najveća primanja ostvaruju u sustavu socijalne skrbi (78\%). Najviše ispitanika ostvaruje doplatak za pomoć i njegu u kući (32,1\%). Naknadu zbog tjelesnog oštećenja ostvaruje $5,5 \%$ ispitanika, a pomoć za uzdržavanje 13,9\%. Osobnu invalidninu ima $28,4 \%$ ispitanika, invalidsku mirovinu $28 \%$, dok plaću ostvaruje njih 16,4\%. Druge izvore prihoda, poput primanja članova obitelji, navodi $21,9 \%$ ispitanika. Osobe s invaliditetom uvelike koriste socijalne transfere. Ranije istraživanje (Leutar, 2006.; Leutar i sur., 2008.) pokazuje da najveći broj ispitanika kao izvore prihoda navodi invalidsku mirovinu $(27,2 \%)$, osobnu invalidninu $(25,4 \%)$, obiteljsku mirovinu $(11,2 \%)$, dok $11,7 \%$ ispitanika ostvaruje vlastitu zaradu.

Oba navedena istraživanja pružaju gotovo identične pokazatelje primanja osoba s invaliditetom, što nudi objektivnu sliku realnoga položaja osoba s invaliditetom unatoč njihovoj provedbi u razmaku od 8 godina.

Slično je i u Nizozemskoj, gdje je shema invalidskog osiguranja ipak najznačajnija zaštita za pola milijuna nezaposlenih (Becker, 2000.). Podaci godišnjeg izvješća Ministarstva zdravstva i socijalne skrbi (MZSS) za 2009. godinu upućuju na 63070 korisnika doplatka za pomoć i njegu, 8950 korisnika osobne invalidnine i 7468 korisnika stalne pomoći (MZSS, 2010.).

Ispitanici materijalne prilike najčešće procjenjuju osrednjima $(58,7 \%)$. Vrlo dobre i odlične materijalne prilike procjenjuje $8,6 \%$ ispitanika, uz $32,6 \%$ koji ih procjenjuju lošima (Tablica 5). 
TABLICA 5

Samoprocjena materijalnih prilika ispitanika

\begin{tabular}{lrr}
\hline & \multicolumn{3}{c}{ Osobe s invaliditetom } \\
Samoprocjena materijalnih prilika & Broj & $\%$ \\
\hline Odlične & 30 & 0,9 \\
Vrlo dobre & 224 & 58,7 \\
Osrednje & 88 & 23,1 \\
Loše & 36 & 9,5 \\
Jako loše & 382 & 100,0 \\
Ukupno & & \\
\hline
\end{tabular}

Na pitanje smatraju li se siromašnom osobom, $34 \%$ ispitanika odgovorilo je da se smatra siromašnim, $22 \%$ ne zna je li siromašno, dok $43 \%$ smatra da nisu siromašni. Samopercepcija materijalnih prilika i siromaštva hi-kvadrat testom pokazala se statistički značajnom $\left(\chi^{2}=191,27 ; \mathrm{df}=8 ; \mathrm{p}<0,01\right)$. Ranija istraživanja (Leutar, 2006.; Leutar i sur., 2008.) imaju sljedeće pokazatelje: materijalne prilike procijenjene su najčešće osrednjima $(49,2 \%)$, uz procjenu $41,7 \%$ ispitanika koji svoje materijalno stanje procjenjuju ispodprosječnim jer ne mogu zadovoljiti osnovne životne potrebe. Samo 1,1\% osoba smatra svoje materijalne prilike odličnima, a 7,9\% dobrima. Druga istraživanja govore općenito o invaliditetu kao riziku za siromaštvo (O'Grady i sur., 2004.; Gordon i sur., 2000.). Međunarodne statistike pokazuju da $20 \%$ siromašnih u svijetu čine upravo osobe s invaliditetom (Elwan, 1999., prema Braithwaite i Mont, 2008.). Siromaštvo i invaliditet međusobno se podupiru, osiguravajući rast isključenosti i osjetljivosti. U zemljama Istočne i Srednje Europe članovi mnogih obitelji često su prisiljeni zbog ekstremnoga siromaštva institucionalizirati svojega člana obitelji s invaliditetom (Inclusion Europe, 2005.). Osobe s invaliditetom smatraju se u mnogim zemljama najsiromašnijima među siromašnima. Stoga Austrija, Češka, Francuska, Irska i Slovenija provode mjere zaštite osoba s invaliditetom od siromaštva, dok u Finskoj i Slovačkoj nisu u dovoljnoj mjeri prepoznate kao osobe s visokim rizikom od siromaštva i socijalne isključenosti (Priestley, 2008.).

Subjektivnu procjenu materijalnih prilika ispitanika pratili su objektivni pokazatelji.

Rezultati pokazuju da $50 \%$ ispitanika, bez obzira na veličinu kućanstva, ima prosječna mjesečna primanja između 2000 i 3500 kuna (do $480 €$ ), dok 20\% ispitanika ima prosječna mjesečna primanja do 2000 kuna (do $274 €$ ). Primjerice, od 39 samačkih domaćinstava, 17 ispitanika ostvaruje primanja do 2000 kuna $(274 €), 18$ do 3500 kuna (480 €), a 4 ispitanika do 5000 kuna $(680 €)$. Ako se kao kriterij uzme linija siromaštva za samačko kućanstvo u 2008. godini od 2025,91 kuna (277 €) 
DRUŠ. ISTRAŽ. ZAGREB GOD. 21 (2012),

BR. 1 (115),

STR. 79-100

LEUTAR, Z., BULJEVAC, M. ZAPOSLENOST OSOBA...

\begin{abstract}
$\rightarrow$ TABLICA 6
Prosječna mjesečna primanja kućanstva u zadnja tri mieseca
\end{abstract}

\section{(1) TABLICA 7}

Korelacija varijabli: subjektivne i objektivne procjene materijalnih prilika mjesečno (Državni zavod za statistiku, 2009.), polovica samaca ispitanika živi u siromaštvu. Usporedimo li to sa zemljama EU-a, može se vidjeti da osobe s intelektualnim poteškoćama ostvaruju novčane potpore na temelju osiguranja u iznosu od $45 € \mathrm{u}$ Rumunjskoj i Bugarskoj, oko $60 € \mathrm{u}$ Mađarskoj i Estoniji, $250 €$ u Grčkoj, $600 €$ u Francuskoj, Njemačkoj i Irskoj te $1600 €$ u Danskoj (Inclusion Europe, 2005.). Analizom ovih podataka može se zaključiti da su primanja u Hrvatskoj nešto bolja od nekih zemalja u Istočnoj Europi, a znatno lošija od zemalja Zapadne Europe i skandinavskih zemalja, koje imaju izdašnije socijalne transfere.

Prosječna mjesečna primanja

kućanstva u zadnja tri mjeseca

Osobe s invaliditetom

Broj $\quad \%$

\begin{tabular}{lrr}
\hline Do 2000 kuna & 69 & 19,8 \\
Od 2001 do 3500 kuna & 106 & 50,0 \\
Od 3501 do 5000 kuna & 93 & 26,6 \\
Od 5001 do 7000 kuna & 48 & 13,6 \\
Od 7001 i više & 34 & 9,8 \\
Ukupno & 351 & 100,0
\end{tabular}

Kako biste procijenili

Smatrate li se siromašnom osobom? materijalne prilike svojega kućanstva?
Koliki je, po Vašoj procjeni, prosječni mjesečni prihod zadnja 3 mjeseca svih članova Vašega kućanstva?

Smatrate li se siromašnom osobom? 1 $-0,438(++)$

$0,320(++)$

Kako biste procijenili materijalne prilike svojega kućanstva?

Koliki je, po Vašoj procjeni, prosječni mjesečni prihod zadnja 3 mjeseca svih članova Vašega kućanstva?

$++\mathrm{p}<0,01$

Korelacija između tri promatrane varijable potvrdila je dosadašnju analizu. Radi se o visokoj međusobnoj korelaciji između varijabli koje govore o subjektivnom doživljaju materijalne situacije i objektivnim pokazateljima. Nakon dosadašnje analize zaista se može govoriti o lošim materijalnim prilikama osoba s invaliditetom u Hrvatskoj i invaliditetu kao jednom od rizika siromaštva (Šućur, 2005.). Siromaštvo se sma- 
(1) TABLICA 8

Statistički značajne razlike s obzirom na sociodemografske pokazatelje $u$ analizi zaposlenih i

nezaposlenih osoba s invaliditetom tra jednim od osnovnih uzroka invaliditeta (WHO, 1995., prema Spicker i sur., 2007.), dok invaliditet u obitelji može dovesti do propadanja ekonomske sigurnosti obitelji i time pridonosi nastanku siromaštva (Townsend, 1979., prema Spicker i sur., 2007.). Stoga se može govoriti o cirkularnom krugu siromaštva i invaliditeta, odnosno uzročno-posljedičnoj vezi.

\begin{tabular}{lrrr}
\hline Zaposlene i nezaposlene osobe s invaliditetom & $\chi^{2}$ & df & $\mathrm{p}$ \\
\hline Samoprocjena materijalnih prilika & 12,82 & 4 & 0,01 \\
Smatrate li se siromašnom osobom & 14,08 & 2 & 0,001 \\
Prosječna materijalna primanja & 16,54 & 4 & 0,002 \\
\hline
\end{tabular}

Rezultati pokazuju statistički značajne razlike između zaposlenih i nezaposlenih osoba $\mathrm{s}$ invaliditetom u procjeni subjektivnih i objektivnih pokazatelja materijalnih prilika. $\mathrm{Na}$ temelju rezultata hi-kvadrat testa uočavaju se značajne razlike na sve tri promatrane varijable. Zaposlene osobe s invaliditetom imaju prosječna mjesečna primanja iznad 5000 kuna u $43 \%$ slučajeva, a nezaposlene u $19 \%$. Primanja manja od 2000 kuna ima 23,7\% nezaposlenih osoba s invaliditetom, a $9,7 \%$ zaposlenih. Gotovo iste rezultate pokazuje istraživanje Leutar i Milić Babić (2008.). Rezultati upućuju na težak ekonomski status osoba s invaliditetom, uz izrazito težak status nezaposlenih osoba s invaliditetom.

Zapošljavanje omogućuje integraciju u zajednicu osoba s invaliditetom. Stoga se analizirala skala uključenosti u zajednicu s obzirom na zaposlene i nezaposlene osobe s invaliditetom. Provedena je ranije navedena faktorska analiza 6 varijabli koje su se odnosile na iskorištavanje osobnih potencijala

(1) TABLICA 9

Prosječne vrijednosti uključenosti u zajednicu za život u zajednici, informiranost o događajima u zajednici, korištenje resursa i sudjelovanje u aktivnostima u zajednici kojom je dobiven jedan faktor "uključenosti u zajednicu".

\begin{tabular}{lccccc}
\hline & N & Min. & Max. & M & SD \\
\hline Uključenost u zajednicu & 314 & 1 & 5 & 2,14 & 0,91 \\
\hline
\end{tabular}

Rezultat pokazuje rijetku uključenost osoba s invalidite-

(1) TABLICA 10

Uključenost u zajednicu i radni status ispitanika tom $\mathrm{u}$ život zajednice. Stoga se analiziralo postoje li razlike s obzirom na zaposlenost osoba s invaliditetom i uključenost $u$ zajednicu.

\begin{tabular}{lrrrrrr}
\hline Radni status & Broj & M & SD & $t$ & df & p \\
\hline Zaposleni & 39 & 2,73 & 0,84 & 5,076 & 165 & 0,000 \\
Nezaposleni & 128 & 1,95 & 0,83 & & & \\
\hline
\end{tabular}


DRUŠ. ISTRAŽ. ZAGREB

BR. $1(115)$

STR. 79-100 ZAPOSLENOST OSOBA... GOD. 21 (2012)

LEUTAR, Z., BULJEVAC, M.

T-testom su dobivene statistički značajne razlike uključenosti osoba s invaliditetom $\mathrm{u}$ život zajednice s obzirom na zapošljavanje $(\mathrm{t}=5,076 ; \mathrm{df}=165 ; \mathrm{p}<0,000)$. Analizom prosječnih vrijednosti i raspršenošću podataka oko aritmetičke sredine vidi se da su zaposlene osobe mnogo češće uključene u život zajednice, dok su nezaposlene osobe u većoj mjeri isključene. Potts (2005.) navodi kako su ljudski, kulturni i socijalni kapital ključni u pronalasku posla. Stoga socijalna isključenost osoba s invaliditetom i dovodi do nemogućnosti pronalaska zaposlenja i postizanja veće kvalitete života, dok nezaposlenost produbljuje socijalnu isključenost.

\section{ZAKLJUČNO RAZMATRANJE}

Na temelju komparativne analize zemalja EU-a i Hrvatske, mogu se prepoznati poveznice Hrvatske sa zemljama EU-a u kontekstu zapošljavanja osoba s invaliditetom. U zemljama EU-a, kao i u Hrvatskoj, postoje trendovi zapošljavanja na otvorenom tržištu rada. Najčešće je prisutno kvotno zapošljavanje osoba s invaliditetom. Zapošljavanje u zaštitnim radionicama i samozapošljavanje uvelike je još uvijek prisutno u zemljama EU-a, unatoč ulaganjima u integraciju osoba s invaliditetom $\mathrm{u}$ otvoreno tržište rada. Najviše su stope zaposlenosti osoba s invaliditetom u Austriji, Danskoj, Švedskoj i Ujedinjenom Kraljevstvu. Između 31 i 50\% zaposlenih je u Belgiji, Irskoj, Francuskoj, Nizozemskoj i Estoniji, dok stope zaposlenih od 10\% do 30\% bilježe Finska, Španjolska, Italija, Mađarska, Litva, Latvija, Malta. Hrvatska se nalazi među zemljama Europe s najnižim stopama zaposlenih osoba s invaliditetom (10\%), dok stope niže od nje imaju Slovačka, Bugarska i Rumunjska. Može se zaključiti da su najviše stope zaposlenih osoba s invaliditetom u skandinavskim državama i državama Srednje Europe, uz najveću nezaposlenost osoba s invaliditetom u državama Istočne Europe.

Hrvatska pripada državama s visokom nezaposlenosti osoba s invaliditetom. Rezultati ovog istraživanja pokazuju da zaposlene osobe najčešće rade puno radno vrijeme, imaju ugovor o radu na neodređeno i posao procjenjuju zanimljivim. Zaposlenost se pokazala statistički značajnom s vremenom nastanka invaliditeta, vrstom završene škole i postignutim stupnjem obrazovanja. Češće su zaposlene osobe s višim stupnjem obrazovanja, obrazovane $u$ redovitom sustavu školovanja i kod kojih je invaliditet nastupio u odrasloj dobi.

Analiza zaposlenih i nezaposlenih osoba s invaliditetom pokazala je da je zaposlenost usko povezana s boljom subjektivnom i objektivnom procjenom materijalnih prilika. Općenito se može reći na temelju ovog istraživanja da osobe s inva- 
DRUŠ. ISTRAŽ. ZAGREB GOD. 21 (2012), BR. 1 (115)

STR. $79-100$

LEUTAR, Z., BULJEVAC, M.: ZAPOSLENOST OSOBA...

\section{LITERATURA}

dan od rizika siromaštva. Ako se radi o nezaposlenim osobama s invaliditetom, rizik je znatno izraženiji.

Uključenost $u$ zajednicu pokazala se statistički značajnom s obzirom na zaposlenost osoba s invaliditetom. Iako se radi o lošijoj uključenosti osoba s invaliditetom u život zajednice općenito, ovo istraživanje pokazalo je mnogo veću integraciju zaposlenih osoba s invaliditetom u zajednicu.

Gotovo identične rezultate pokazuju i ranija istraživanja u Hrvatskoj (Leutar i Milić Babić, 2008.; UNDP, 2008.; Babić i Leutar, 2010.). Rezultati ovog istraživanja upućuju na potrebu rada na preduvjetima zapošljavanja na otvorenom tržištu rada ulaganjem u obrazovanje osoba s invaliditetom za zanimanja koja su zapošljiva i konkurentna na otvorenom tržištu rada, potom poticanjem i razvijanjem programa formalnog i neformalnog obrazovanja u svim životnim razdobljima i ulaganjem $u$ što veću integraciju osoba s invaliditetom $u$ društvu. Ulaganjem u zapošljavanje osoba s invaliditetom smanjuje se rizik siromaštva osoba s invaliditetom i omogućuje njihov ravnopravniji život u društvenoj zajednici.

Babić, Z. i Leutar, Z. (2010.), Položaj osoba s invaliditetom na tržištu rada Republike Hrvatske. Socijalna ekologija, 19 (2): 195-213.

Becker, U. (2000.), Welfare State Development and Employment in the Netherlands in Comparative Perspective. Journal of European Social Policy, 10 (3): 219-239.

Bengtsson, S. (2009.), Report on the Employment of Disabled People in European Countries - Denmark, Utrecht, ANED. http://www.disabilityeurope.net/content/pdf/DK\% 20-\%20ANED\% 202009\%20Employ ment\%20Report\%20Final.pdf (10. 8. 2010.)

Benjak, T. (2011.), Izvješće o osobama s invaliditetom u Republici Hrvatskoj, Zagreb, Hrvatski zavod za javno zdravstvo, Služba za epidemiologiju kroničnih masovnih bolesti. http://www.hzjz.hr/epidemiologija/ kron_mas/invalidi10.pdf (18. 5. 2011.)

Braithwaite, J. i Mont, D. (2008.), Disability and Poverty: A Survey of World Bank Poverty Assessments and Implications, The World Bank.

Burton, C. i O'Mahony, C. (2009.), Report on the Employment of Disabled People in European Countries - Ireland, Utrecht, ANED. http:/www. disability-europe.net/content/pdf/IE\% 20-\% 20ANED \% 202009\% 20 Employment\%20Report\%20Final.pdf (21. 8. 2010.)

Calite, D. (2009.), Report on the Employment of Disabled People in European Countries - Latvia, Utrecht, ANED. http://www.disabilityeurope.net/content/pdf/LV-12-ANED\% 202009\% 20Task\% 206 $\%$ 20Request-08B-Country \%20update\%20Employment $\% 20-\% 20$ report_final.pdf (13. 7. 2010.)

Ceccotto, R. (2008.), Report on the Employment of Disabled People in European Countries - Luxembourg, Utrecht, ANED. http://www.disabilityeurope.net/content/pdf/LU\%20employment\%20report.pdf (1. 9. 2010.) 
DRUŠ. ISTRAŽ. ZAGREB GOD. 21 (2012) BR. $1(115)$

STR. $79-100$

LEUTAR, Z., BULJEVAC, M. ZAPOSLENOST OSOBA...
Danermark, B. (2009.), Report on the Employment of Disabled People in European Countries - Sweden, Utrecht, ANED. http://www.disabilityeurope.net/content/pdf/SE\% 20-\%20ANED\% 202009\%20Employment $\%$ 20Report\% 20Final.pdf (23. 8. 2010.)

Devlieger, P. J. (2008.), Report on the Employment of Disabled People in European Countries - Belgium, Utrecht, ANED. http://www.disabilityeurope.net/content/pdf/BE\%20employment\%20report.pdf (2. 7. 2010.)

Državni zavod za statistiku (2001.), Popis stanovništva 2001. http://www. dzs.hr/ (12. 2. 2011.)

Državni zavod za statistiku (2009.), Priopćenja i statistička izvješća Pokazatelji siromaštva 2009. http://www.dzs.hr (5. 4. 2011.)

European Communities (2003.), Employment of Disabled People in Europe in 2002, Population and Social Conditions, 3 (26).

European Disability Forum (2003.), Disability and Social Exclusion in the European Union. Time for Change, Tools for Change - Final Study Report, European Disability Forum.

Eurostat (2010.), Combating Poverty and Social Exclusion - A Statistical Portrait of the European Union 2010, Belgium, European Commission.

Flaker, V., Dolinšek, T., Nagode, M., Zaviršek, D. i Gorenc, D. (2009.), Report on the Employment of Disabled People in European Countries Slovenia, Utrecht, ANED. http://www.disability-europe.net/content/ pdf/SI \%20ANED \% 202009\% 20Employment $\% 20$ Report $\% 20$ Final.pdf (12. 9. 2010.)

Gannon, B. i Nolan, B. (2005.), Disability and Social Inclusion in Ireland, Dublin, The Equality Authority and the National Disability Authority.

Ghergut, A. i Gavrilovici, O. (2008.), Report on the Employment of Disabled People in European Countries - Romania, Utrecht, ANED. http:// www.disability-europe.net/content/pdf/RO\%20Employment $\%$ 20report.pdf (17. 8. 2010.)

Gordon, D., Levitas, R. A., Pantazis, C., Payne, S., Patsios, D. i Townsend, P. B. (2000.), Poverty and Social Exclusion in Britain, York, Joseph Rowntree Foundation.

Goss, D., Goss, F., Adam-Smith, D. (2000.), Disability and Employment: A Comparative Critique of UK Legislation. The International Journal of Human Resource Management, 11 (4): 807-821. doi:10.1080/ 09585190050075132

Grammenos, S. (2003.), Illness, Disability and Social Inclusion, Dublin, European Foundation for the Improvement of Living and Working Conditions.

Hanzelova, E., Brichtova, L. i Repkova, S. (2009.), Report on the Employment of Disabled People in European Countries - Slovakia, Utrecht, ANED. http://www.disability-europe.net/content/pdf/SK-\% 20ANED \%202009\% 20Employment\%20Report\%20Final.pdf (13. 9. 2010.)

Hrvatski zavod za zapošljavanje (HZZ) (2010.), Izvješća o aktivnostima hrvatskoga zavoda za zapošljavanje u području zapošljavanja osoba s invaliditetom. http://www.hzz.hr (31. 8. 2010.)

Hrvatski zavod za zapošljavanje (HZZ) (2011.), Položaj osoba s invaliditetom na tržištu rada. http://www.hzz.hr/default.aspx?id=5116 (13. 3. 2011.) 
DRUŠ. ISTRAŽ. ZAGREB GOD. 21 (2012), BR. 1 (115),

STR. $79-100$

LEUTAR, Z., BULJEVAC, M.: ZAPOSLENOST OSOBA...
Inclusion Europe (2005.), Poverty and Intellectual Disability in Europe, Brussels, Inclusion Europe.

International Disability Rights Monitor (2007.), Regional Report of Europe 2007, Chicago, International Disability Network.

Kiš-Glavaš, L. (2009.), Aktivnosti i prepreke u zasnivanju radnog odnosa za osobe s invaliditetom. Hrvatska revija za rehabilitacijska istraživanja, 45 (1): 63-72.

Koenig, O. (2009.), Report on the Employment of Disabled People in European Countries - Austria, Utrecht, ANED. http://www.disability-europe. net/content/pdf/AT-\%20ANED\% 202009\% 20Employment\%20Report\% 20Final.pdf (12. 7. 2010.)

Konczei, G. i Horvath, P. (2008.), Report on the Employment of Disabled People in European Countries: Hungary, Utrecht, ANED. http://www. disability-europe.net/content/pdf/HU\% 20Employment\%20report. pdf (23. 8. 2010.)

Kummissjoni Nazzjonali Persuni B'dizabilita (2009.), Report on the Employment of Disabled People in European Countries - Malta, Utrecht, ANED. http://www.disability-europe.net/content/pdf/MT\%20-\%20 ANED \%202009\%20Employment\%20Report\%20Final.pdf (26. 8. 2010.)

Leutar, Z. (2005.), Employing People with Disabilities in Croatia. South-East Europe Review, S. 77-90.

Leutar, Z. (2006.), Osobe s invaliditetom i siromaštvo. Revija za socijalnu politiku, 13 (3-4): 293-398. doi:10.3935/rsp.v13i3.428

Leutar, Z. i Milić Babić, M. (2008.), Pravo na rad i osobe s invaliditetom u RH. Sociologija i prostor, 180 (2): 161-187.

Leutar, Z., Ogresta, J. i Milić Babić, M. (2008.), Obitelji osoba s invaliditetom i mreže podrške, Zagreb, Pravni fakultet Sveučilišta u Zagrebu.

Leutar, Z. (2009.), Familiare Wertorientierungen im Vergleich, Saarbrucken, Sudwestdeutscher Verlag fur Hochschulschrifter Aktiengesellschaft \& Co.

Mete, C. (2008.), Economic Implications of Chronic Illness and Disability in Eastern Europe and the Former Soviet Union, Washington, The World Bank.

Micangeli, A., Puglisi, A. i Vignola, R. (2009.), Report on the Employment of Disabled People in European Countries - Italy, Utrecht, ANED. http://www.disability-europe.net/content/pdf/IT\%20Employment\% 20report.pdf (27. 8. 2010.)

Ministarstvo zdravstva i socijalne skrbi (2010.), Godišnje statističko izvješće o domovima i korisnicima socijalne skrbi u Republici Hrvatskoj u 2009. godini. http://www.mzss.hr/hr/zdravstvo_i_socijalna_skrb/socijalna skrb/statisticka_izvjesca/godisnje_izvjesce_2008 (2. 9. 2010.)

O'Grady, A., Pleasence, P., Balmer, N. J., Buck, A. i Gen, H. (2004.), Disability, Social Exclusion and the Consequential Experience of Justiciable Problems. Disability and Society, 19 (3): 259-272. doi:10. 1080/0968759042000204158

Pagan, R. (2007.), Is Part-Time Work a Good or Bad Opportunity for People with Disabilities? A European Analysis. Disability and Rehabilitation, 29 (24): 1910-1919. 
DRUŠ. ISTRAŽ. ZAGREB GOD. 21 (2012), BR. 1 (115),

STR. 79-100

LEUTAR, Z., BULJEVAC, M. ZAPOSLENOST OSOBA...
Pagan, R. (2009.) Self-Employment among People with Disabilities: Evidence for Europe. Disability \& Society, 24 (2): 217-229.

Panayotova, K. (2009.), Report on the Employment of Disabled People in European Countries - Bulgaria, Utrecht, ANED. http://www.disabilityeurope.net/content/pdf/BG-ANED\% 202009\% 20Employment $\% 20$ Report\%20Final.pdf (9. 7. 2010.)

Paun Jarallah, A. (2008.), Aktivnosti hrvatskog zavoda za zapošljavanje u obrazovanju i zapošljavanju osoba s invaliditetom. U: A. Paun Jarallah (ur.), Zbornik radova simpozija Obrazovanje i zapošljavanje osoba s invaliditetom: iskustva, novi smjerovi (str. 31-35), Zagreb, HZZ.

Pimenta, A. i Marques, A. (2009.), Report on the Employment of Disabled People in European Countries - Portugal, Utrecht, ANED. http://www. disability-europe.net/content/pdf/PT-\% 20ANED\%202009\%20Em ployment\%20Report\%20Final.pdf (10. 9. 2010.)

Priestley, M. (2008.), Synthesis Report on Disability Mainstreaming in the 2008-2010 National Strategy Reports for Social Protection and Social Inclusion, Utrecht, ANED.

Potts, B. (2005.), Disability and Employment: Considering the Importance of Social Capital. Journal of Rehabilitation, 71 (3): 20-25.

Roulstone, A., Prideaux, S., Priestley, M. i Woodin, S. (2009.), Report on the Employment of Disabled People in European Countries - United Kingdom, Utrecht, ANED. http://www.disability-europe.net/content/pdf/ UK\% 20-\% 20ANED\% 202009\%20Employment\% 20Report\% 20Final. pdf (13. 9. 2010.)

Ruškus, J. (2009.), Report on the Employment of Disabled People in European Countries - Lithuania, Utrecht, ANED. http://www.disabilityeurope.net/content/pdf/LT-11-ANED\% 202009\% 20Task\% 206 $\%$ 20Request-08B $\% 20-\%$ 20Country $\% 20$ update $\% 20$ Employment $\% 20$ \%20report\% 20-\%20final.pdf (22. 8. 2010.)

Sakkeus, L., Pall, K., Tampere, H. i Kreitzberg, M. (2009.), Report on the Employment of Disabled People in European Countries - Estonia, Utrecht, ANED. http://www.disability-europe.net/content/pdf/EE\%20-\%20ANED $\%$ 202009\%20Employment\%20Report\%20Final.pdf (13. 7. 2010.)

Schoonheim, J. i Smits, J. C. (2009.), Report on the Employment of Disabled People in European Countries - Netherlands, Utrecht, ANED. http://www.disability-europe.net/content/pdf/NL-10-ANED\%202009 $\%$ 20Task\% 206\%20Request-08B-Country\%20update\%20Employment \%20-\%20report\%20-\%20final.pdf (21. 8. 2010.)

Shima, I., Zólyomi, E. i Zaidi, A. (2008.), The Labour Market Situation of People with Disabilities in EU25, Vienna, European Centre for Social Welfare Policy and Research.

Skočić Mihić, S. i Pinoza Kukurin, Z. (2009.), Teškoće pri zapošljavanju i radu osoba s oštećenjima vida percipirane od strane poslodavaca. Hrvatska revija za rehabilitacijska istraživanja, 45 (1): 51-62.

Soritsch, A. (2004.), Living with Disabilities in Austria - With a Special Focus on the Capital. Collegium Antropologicum, 28 (2): 31-42.

Spicker, P., Leguizamón, S. A. i Gordon, D. S. (2007.), Disability and Poverty. U: Spicker, P., Leguizamón, S. A. i Gordon, D. S. (ur.), Poverty: An International Glossary (str. 56), London, Zed Books. 
DRUŠ. ISTRAŽ. ZAGREB GOD. 21 (2012), BR. 1 (115) STR. $79-100$

LEUTAR, Z., BULJEVAC, M. ZAPOSLENOST OSOBA...
Strati, E. i Evangelinou, A. (2009.), Report on the Employment of Disabled People in European Countries - Greece, Utrecht, ANED. http:// www.disability-europe.net/content/pdf/EL\% 20-\%20ANED\%202009 \%20Employment\%20Report\%20Final.pdf (13. 7. 2010.)

Symeonidou, S. (2008.), Report on the Employment of Disabled People in European Countries - Cyprus, Utrecht, ANED. http://www.disabilityeurope.net/content/pdf/CY\%20Employment\%20report.pdf (8. 7. 2010.)

Šiška, J. (2009.), Report on the Employment of Disabled People in European Countries - Czech Republic, Utrecht, ANED. http://www.disability-europe. net/content/pdf/CZ\% 20-\% 20ANED\% 202009\% 20Employment $\% 20$ Report\% 20Final.pdf (10. 7. 2010.)

Šućur, Z. (2005.) Siromaštvo i socijalni transferi u Hrvatskoj. Financijska teorija i praksa, 29 (1): 37-58.

UNDP - Program Ujedinjenih naroda za razvoj (2008.), Zapošljivost nezaposlenih osoba s invaliditetom, Zagreb, Program Ujedinjenih naroda za razvoj.

Velche, D., Ville, I. i Ravand, J-F. (2009.), Report on the Employment of Disabled People in European Countries - France, Utrecht, ANED. http:// www.disability-europe.net/content/pdf/FR-9-ANED $\% 202009 \%$ 20Task $\% 206 \%$ 20Request-08B-Country\%20update $\% 20$ Employment \%20-\%20report\%20final.pdf (19. 8. 2010.)

Verdugo, M. A., Jenaro, C. i Campo, M. (2009.), Report on the Employment of Disabled People in European Countries - Spain, Utrecht, ANED. http://www.disability-europe.net/content/pdf/ES\% 20-\%20ANED $\%$ 202009\% 20Employment\%20Report\%20Final.pdf (23. 8. 2010.)

Waldschmidt, A., Lingnau, K. i Meinert, S. (2009.), Report on the Employment of Disabled People in European Countries - Germany, Utrecht, ANED. http://www.disability-europe.net/content/pdf/DE\%20-\%20 ANED \%202009\%20Employment\%20Report\% 20Final.pdf (5. 7. 2010.) Wapiennik, E. (2009.), Report on the Employment of Disabled People in European Countries - Poland, Utrecht, ANED. http://www.disabilityeurope.net/content/pdf/PL-11-ANED\% 202009\% 20Task\% 206\% 20 Request-08B-Country $\% 20$ update $\% 20$ Employment $\% 20-\% 20$ final.pdf (12. 9. 2010.)

Zakon o potvrđivanju Konvencije o pravima osoba s invaliditetom i fakultativnog protokola uz konvenciju o pravima osoba s invaliditetom. Narodne novine, br. 6/2007., 3/2008., 5/2008.

Zakon o profesionalnoj rehabilitaciji i zapošljavanju osoba s invaliditetom. Narodne novine, br. 143/2002., 33/2005. 
DRUŠ. ISTRAŽ. ZAGREB GOD. 21 (2012),

BR. 1 (115)

STR. 79-100

LEUTAR, Z., BULJEVAC, $M$ ZAPOSLENOST OSOBA..

\section{Employment of People with Disabilities in Croatia and the Member States of the European Union}

Zdravka LEUTAR, Marko BULJEVAC

Faculty of Law, Zagreb

The introductory chapter presents the basic features of the employment of people with disabilities in 27 Member States of the European Union (EU) and Croatia. This is followed by a presentation of findings of the project "Social status of people with disabilities in Croatia" in the context of people with disabilities' employment in Croatia. The aim of the paper is to examine some characteristics of employed people with disabilities in Croatia and to compare them with the employment of people with disabilities in the Member States of the European Union, to determine the material conditions of people with disabilities in Croatia and community involvement of those who are employed. The research indicates that the employment of people with disabilities in Croatia is about $10 \%$. The differences in employment according to the level of education, form of education and time when disability occurred were significant. The correlation between self-assessment and objective assessment of material conditions, employment and community involvement was also significant. The average employment of people with disabilities in Croatia and in the Member States of the European Union is very similar, e.g. the employment quota system in the open labor market prevails in the Member States of the European Union and in Croatia too. It is necessary to invest in the education of people with disabilities and to educate them for professions that will provide their employment in the open labor market. Also their involvement in the community must be encouraged.

Keywords: employment, Croatia, Member States of the European Union, education, community involvement 